\title{
ENGINE CONTROL UNIT BASED ON THE NI COMPACTRIO
}

PLATFORM

\author{
MICHAL STRAPKO \\ Sládkova 4970, Chomutov, 430 03, E-mail: michal.strapko@gmail.com \\ RADEK TICHÁNEK
}

CTU in Prague, Faculty of Mechanical Engineering, Technická 4, 16607 Praha 6, Tel.: +420224352507, E-mail: radek.tichanek@fs.cvut.cz

\section{SHRNUTÍ}

Byla vyvinuta programovatelná rídicí jednotka na platformě CompactRIO s programem vytvořeným v prostředí LabVIEW. Jednotka byla vyvijena jako univerzální a byla testována prì řizení malého zážehového motoru YAMAHA YZF R6. Jednotka je dále použitelná pro zážehové motory různé koncepce, přeplňované i nepřeplňované. Požadavku na univerzálnost jednotky byl přizpůsoben ř́dící program, který je uspořádán ve vzájemně komunikujicích samostatných blocích. Zařizení je rozširiitelné o další l/O moduly, což umožňuje použití dalších snímačů, aktuátorů nebo modulů pro komunikaci. Rozhraní pro zesílení výstupů napájejićích zapalování a vstriikovače bylo vyvinuto pro řízení motoru YAMAHA YZF R6. Toto zařízení zároveň stabilizuje napájení snímačů motoru a filtruje jejich výstupní signály. Článek je shrnutím procesu vývoje řídíí jednotky motoru, obsahuje přehled použitých zařízení, seznamuje s řídíím programem a zkušenostmi z testování na motoru.

\section{KLIČCVÁ SLOVA: ŘíDÍCI JEDNOTKA MOTORU, COMPACTRIO, LABVIEW}

\section{ABSTRACT}

A programmable engine management system based on the NI CompactRIO platform and LabVIEW software was developed and used as an engine control unit (ECU) for a YAMAHA YZF R6. The unit was developed as a universal tool for engine control, and the unit has been tested on a test rig with a small gasoline engine, the Yamaha YZF R6. The unit is also applicable for gasoline engines, different concepts, supercharged and naturally aspirated. The universality of the unit is due to being adapted to a control program, which is arranged in separate mutually communicating blocks. The device is expandable with additional I / 0 modules, allowing the use of additional sensors, actuators, and communication modules. An interface for amplification of the CompactRIO outputs for ignition and injection has been developed for Yamaha YZF R6 engine control. This device also stabilizes voltage for sensors, and filters the output signals. The article is a summary of the development process for an engine control unit, and includes an overview of the equipment, introduces the control program and the experience of testing on the engine.

\section{KEY WORDS: ENGINE CONTROL UNIT, COMPACTRIO, LABVIEW}

\section{MOTIVATION}

Stock engines are widely used for research purposes as the base engines for further research and development of their components, optimization of their engine management and related experimental work. Experimental work on an IC engine usually requires changes in its engine control unit (ECU) data, particularly in cases where the engine management lacks any adaptive control. A standard used in automotive industry for ECU development is the ETAS INCA software [6]. This tool provides an integrated environment for measurement, ECU calibration and engine diagnostics. The cost of the software and the required hardware for ECU connection is beyond the budget of most institutions, such as universities and small research centers. In some cases the ETAS system is more robust than is needed when the main objective is not the development of a completely new ECU for the automotive industry. On the other hand, there are many other programmable ECUs used mainly in motorsport, but these are not suited for research purposes because they have limited programming capabilities. The units usually have only editable tables, use predefined inputs and the options for choosing outputs are finite. Developing an ECU based on NI CompactRIO equipment was chosen as a solution which is cost effective. The new ECU provides the required flexibility, programming capabilities and independent control. 


\section{INTRODUCTION}

The motorcycle engine YAMAHA YZF R6 was chosen for the developing and testing of a CompactRIO based ECU because this engine has simple electronics and engine control. The engine is also used in the CTU Formula Student car, and thus provides an opportunity to engage more students in the research work. However, the developed engine management system is usable for other engines as the system is graphically programmed using LabVIEW and the programming philosophy is user friendly.

Figure 1 shows a schematic of YAMAHA YZF R6 engine management. The engine fuel system of the Yamaha YZF R6 engine comprises two groups of injectors, which are located in the intake manifold at different distances from the intake valve. The primary injectors (Fig. 1, link 1) operate across the entire engine speed range, while the secondary injectors deliver fuel

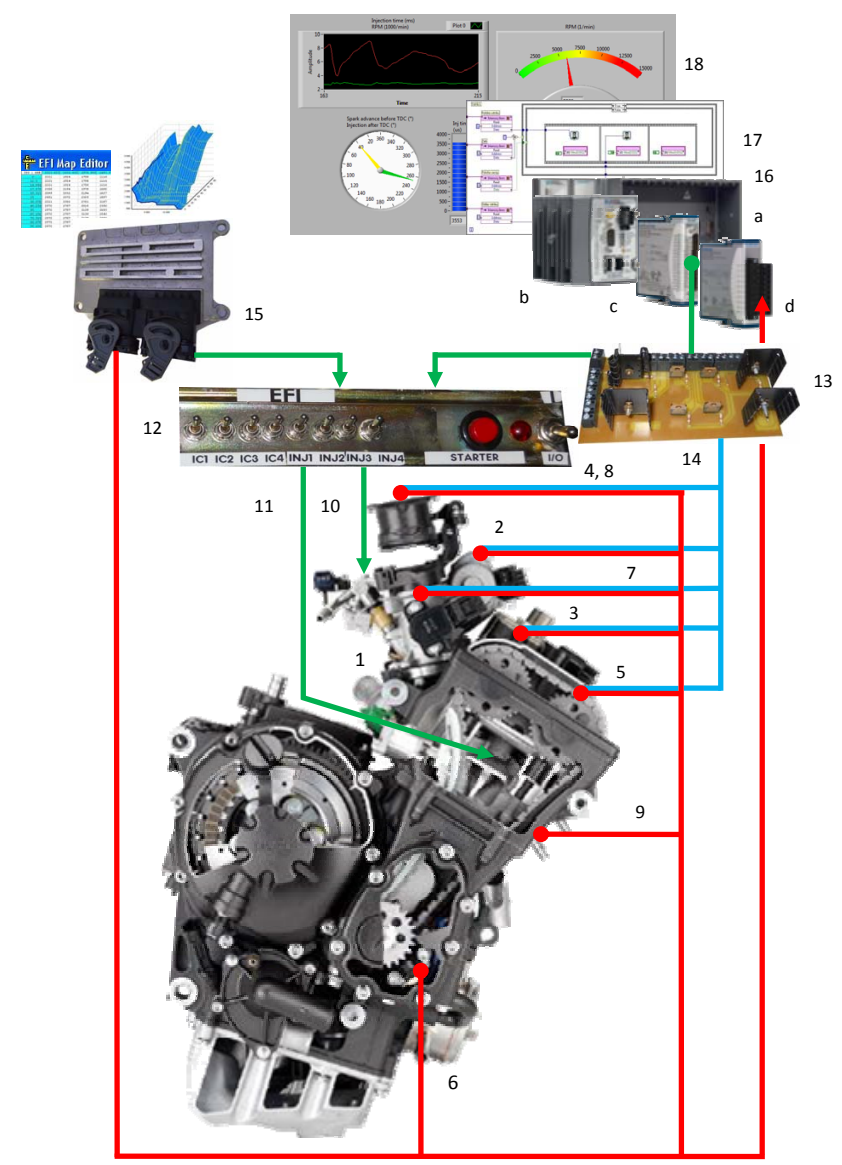

FIGURE 1: YAMAHA YZF R6 engine management scheme [1],[3],[4],[5]. OBRÁZEK 1: Schéma řízení motoru YAMAHA YZF R6.

- 1. Primary injectors $\bullet 2$. Throttle position sensor $\bullet$ 3. Coolant temperature sensor $\bullet$ 4. Atmospheric pressure sensor $\bullet$ 5. Camshaft position sensor $\bullet 6$. Crankshaft position sensor $\bullet 7$. Intake air pressure sensor $\bullet$ 8. Air temperature sensor $\bullet 9.02$ sensor $\bullet 10$. Injection control - 11. Ignition control $\bullet$ 12. Control bridge $\bullet$ 13. Interface $\bullet$ 14. Voltage of sensors • 15. EFI Euro 4 ECU • 16. CompactRIO system (a-FPGA chassis NI9104, b- NI9012 real-time controller, c- module of outputs, d- module of inputs NI9201) • 17. LabVIEW software • 18. Information panel only at higher engine speeds. The secondary injectors are placed in the engine airbox. Such an arrangement is to ensure the delivery of a homogeneous mixture into the engine cylinder over the entire engine speed range, and fast engine response during transient operation. The volume of injected fuel is controlled by the time the injectors are opened. The injection duration and the injection timing are controlled by the ECU where default values of these variables are stored in the maps.

The injection duration is in general determined from the maps according to signals from the throttle position sensor (Fig. 1, link 2) or intake air pressure sensor (Fig. 1, link 7) and engine speed. The engine speed is determined from the signal of a crankshaft position sensor (Fig. 1, link 6). The outputs of coolant temperature sensor (Fig. 1, link 3), an atmospheric pressure sensor (Fig. 1, link 4), an air temperature sensor (Fig. 1, link 8) and an $\mathrm{O}_{2}$ sensor (Fig. 1, link 9) are used for corrections of basic injection duration. The corrections extend or reduce the time duration depending on the ambient conditions, engine temperature, throttle position, engine speed changes and mixture quality. The injection timing is determined based on signals from the crankshaft position sensor (Fig. 1, link 6) and camshaft position sensor (Fig. 1, link 5).

The engine management system of the YAMAHA YZF R6 engine is specific because the amount of inducted air is not measured directly. In this way the system is similar to the old Bosch D-Jetronic engine management where a control unit determines an amount of a fuel to be injected depending on the amount of inducted air. The amount of inducted air is determined indirectly from measured intake manifold pressure and intake air temperature, engine speed and other factors. The basic fuel volume corresponding to an injection time duration is obtained on the basis of the air amount. The time duration of injection is further corrected depending on the evaluated throttle position and velocity of its position changes. The throttle position sensor indicates the position of the throttle, and the velocity of the position change is simultaneously evaluated. A rapid position change during throttle opening indicates an acceleration requirement, and this as well as wide open or closed throttle results in further correction of injection time duration. The precise control of injection is crucial for this engine because fast engine response to throttle changes is required. The original management of the YAMAHA YZF R6 engine is equipped with closed-loop control of the A/F mixture using the lambda sensor in the exhaust manifold.

\section{NI COMPACTRIO CONFIGURATION}

The developed engine management system combines in-house developed hardware with the modular programmable automation controller CompactRIO made by National Instruments. The 
CompactRIO device combines a real-time controller, I/O modules and an FPGA chassis. Our equipment consists of the real-time controller N19012, which features an industrial $400 \mathrm{MHz}$ real-time processor for deterministic and reliable real-time applications. It contains $64 \mathrm{MB}$ of DRAM memory and a minimum of $128 \mathrm{MB}$ of nonvolatile storage. The module of inputs NI 9201 contains 8 analog inputs and it was used for the connection of output signals from the engine's sensors. The module NI-9478 controls outputs for engine management. The module contains 16 outputs with the option of loading one channel up to $5 \mathrm{~A}$, or up to $1.2 \mathrm{~A}$ if all channels are used. The real time controller and the $1 / 0$ modules are swapped in the chassis NI 9104 with an embedded field-programmable gate array (FPGA).

\section{INTERFACE}

The sensors for measurement of coolant temperature (Fig. 1, link 3), throttle angle (Fig. 1, link 2), atmospheric pressure (Fig. 1, link 4), intake air pressure sensor (Fig. 1, link 7), air temperature (Fig. 1, link 8), crankshaft position sensor (Fig. 1, link 6) and camshaft position sensor (Fig. 1, link 5) are connected to the N19201 module via an in-house developed interface, see the schematic in Figure 2. The interface (Fig. 1, link 13) stabilizes the $5 \mathrm{~V}$ voltage, which is used in the sensors, filters the sensors' outputs via RC filters and amplifies the CompactRIO outputs.
There are embedded transistors for amplifying the current supply for injectors and ignition coils in the interface.

COP type induction coils and shower-type injectors consume a current of approximately $5 \mathrm{~A}$ and $2 \mathrm{~A}$ in the steady state. Such currents can also be switched by the output module CompactRIO units. The problem, however, is the derivative pulse which is generated by the coil when this is disconnected. The induced voltage value is over $100 \mathrm{~V}$. Appropriate energy must be converted into heat, which is achieved by strengthening the CompactRIO outputs using unipolar transistors and backward diodes. Adequate cooling is required for the transistors switching on the inductive coils, because when disconnecting the coils, the transistors are heated by the energy of the coils. Transistors for the injectors can be used without additional cooling. The transistors are covered with T0220 housings.

A $5 \mathrm{~V}$ reference voltage is used by the analog pressure, temperature, camshaft and throttle position sensors. This voltage is stabilized by stabilizer 7805 covered with a TO220 case. The signals from the coolant temperature, pressure and throttle position sensors are filtered by $100 \mu \mathrm{F}$ capacitors, which are connected in parallel with them. All wires are connected via screw terminals for easy installation. The board was designed with regard to the placement of coolers on the transistors. Coolers are placed on the transistors T1, T2, T7 and T8.

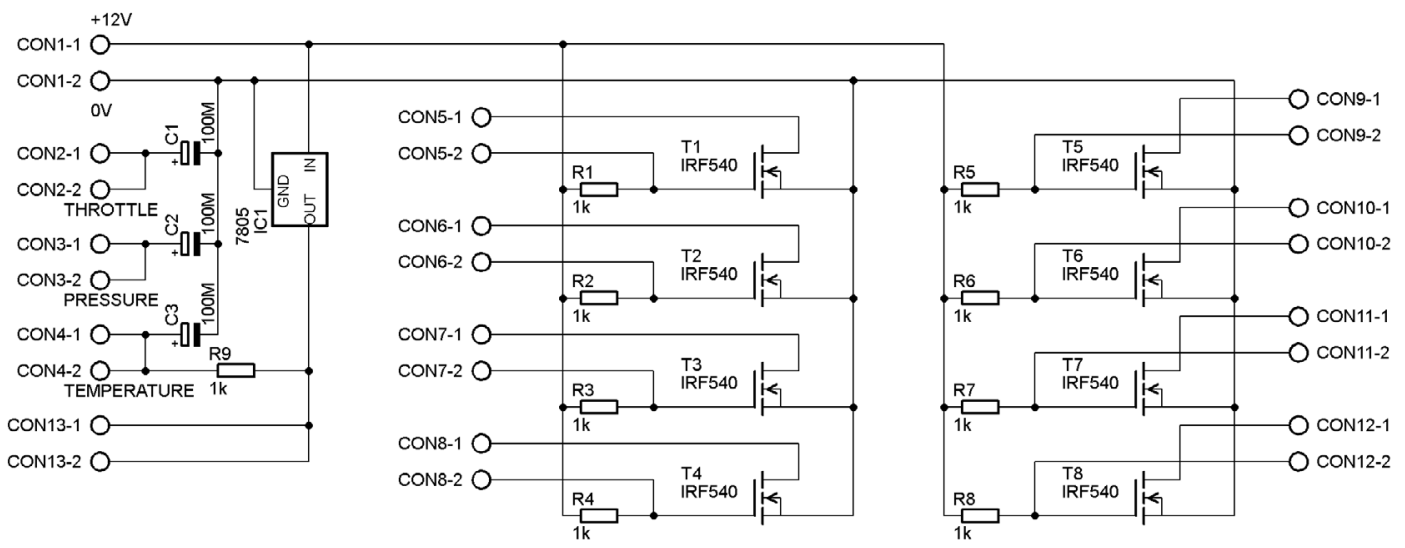

FIGURE 2: Schematic diagram of the interface connecting CompactRIO and the engine [1]. OBRÁZEK 2: Schéma rozhraní spojujícího CompactRIO a motor [1].

\section{FUEL INJECTION AND IGNITION TIMING}

The engine's crankshaft and camshaft position are the main parameters for the control of ignition and fuel injection timing. Their values are determined from the position sensors, and one can calculate the engine speed and the top dead center position of a given piston. The sensors are connected via analog module NI 9201. The camshaft sensor has an output at TTL level and the crankshaft sensor generates analog derivative pulses of approximately $\pm 20 \mathrm{~V}$.
The crankshaft sensor is an inductive sensor which reads the position of the crankshaft gear consisting of 20 teeth and one extended length tooth via 4 teeth (24-4 configuration), see Figure 3. The TDC of the first and fourth cylinder indicates the rising edge of the seventh tooth after passing of the extended tooth through the inductive sensor. The TDC of the second and third cylinder indicates the rising edge of the nineteenth tooth after passing of the extended tooth through the inductive sensor. The camshaft sensor determines the firing TDC position of the second cylinder and the gas exchange TDC of the third cylinder, see Figure 3. The firing TDC of the second cylinder is used for 
the determination of fuel injection and ignition timing because it sets a logical value of a RS circuit. The RS circuit takes values of LOG 1 or LOG 0 and it controls the application of injection or ignition via Table 1. The timing of injection and ignition is calculated as a delay from the TDC of a given cylinder.

Rising edge detection of the extended tooth takes place as follows: if the time between actual teeth is 2 times longer than the average time of the last 4 teeth, then an elongated tooth has passed. Averaging the time of the last 4 teeth also eliminates false detection of the extended tooth during engine acceleration.

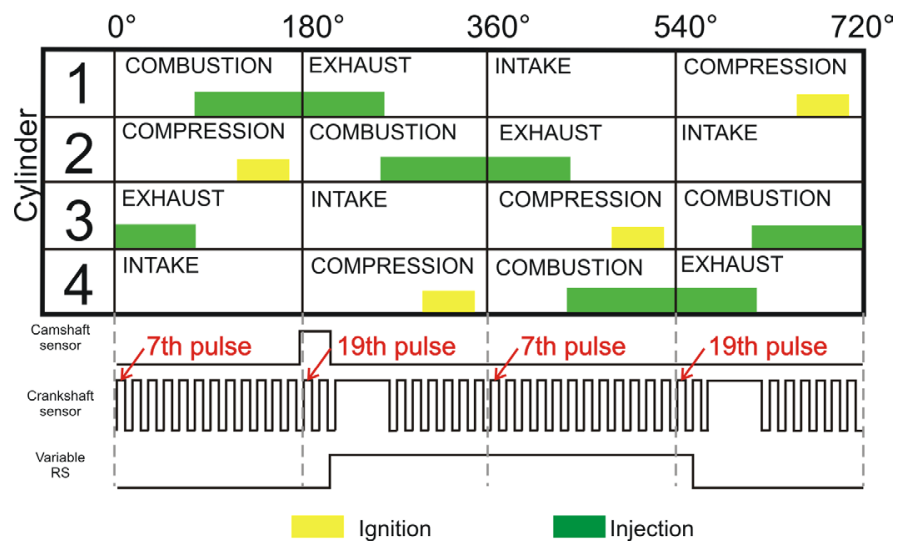

FIGURE 3: The fuel injection and ignition timing scheme of the YAMAHA YZF R6 engine [1].

OBRÁZEK 3:Schéma časování zapalování a vstřikování paliva motoru YAMAHA YZF R6 [1].

\begin{tabular}{|ccl|}
\hline Actuator & Tooth of crankshaft gear & RS circuit value \\
\hline Injector 1 & 7 & LOG 0 \\
\hline Injector 2 & 19 & LOG 1 \\
\hline Injector 3 & 19 & LOG 0 \\
\hline Injector 4 & 7 & LOG 1 \\
\hline Ignition 1 & 19 & LOG 0 \\
\hline Ignition 2 & 7 & LOG 0 \\
\hline Ignition 3 & 7 & LOG 1 \\
\hline Ignition 4 & 19 & LOG 1 \\
\hline
\end{tabular}

TABLE 1: Table of RS circuit values for timing of injection and ignition. TABULKA 1: Tabulka hodnot RS obvodu pro časování vstřikování a zapalování.

\section{NI LABVIEW BASED ECU SOFTWARE}

Software for the ECU based on the CompactRIO was created in the graphical programming language NI LabVIEW. NI LabVIEW programming language is suitable for programming measuring equipment in laboratories, but the software can be programmed for any other applications and the developed code can be compiled into an executable file. The measuring device communicates over many types of interface. The network interface protocol TCP/IP was chosen for communication between the CompactRIO and the computer for which the software has been developed. The base software was developed as part of a bachelor degree project [2]. Software for CompactRIO consists of two separated and mutually communicating programs. The first one is for the real-time controller N19012, see its simplified schematic in Figure 5 . The second one is for the FPGA, which is part of chassis NI9104, see its simplified schematic in Figure 5.

The FPGA program must run synchronously with the running engine. This program applies values that are calculated in the controller. There are three main loops in the sample program, see Figure 4, which represent three main tasks of the FPGA. The first loop determines crankshaft and camshaft position from digital sensors for subsequent usage. The second loop senses data from analog sensors of throttle position, temperature and pressure, and sends them to the controller. The most important function is exact timing of injection and ignition, which is performed by the third loop. The timing is controlled on the basis of signals from camshaft and crankshaft sensors, because from these two signals it is possible to very accurately determine the position of the engine, see Figure 3 .

The program for the controller reads data from the engine's sensors via analog module N19201 and the FPGA program, see a sample of this program in Figure 5 . The program acquires four main values - throttle position, temperature, engine speed and intake pressure. Calculation of the injection duration and ignition timing is based on linear interpolation from the maps, see Figure 5 . Figure 5 shows maps of injection duration, spark advance and correction. Values in the maps depend on the throttle position or intake pressure and engine speed. Values looked up and interpolated from the maps are multiplied by correction factors ensuring compensation of engine temperature. Two main values result from this process - duration of fuel injection and spark advance. These values are sent to the FPGA, where they are exactly applied to the engine. The main algorithms of the controller program were described on the basis of the program sample, because Figure 5 showing the sample is clearer than it would be if it depicted the full program.

Nevertheless, the full program contains a map of injection position and a few loops for ensuring optimal A/F ratio of the mixture during various conditions, for example starting correction, air pressure and temperature correction, acceleration enrichment and engine speed limiter.

The controller program includes a front panel, see Figure 6 . The front panel displays values of the engine sensors (throttle position, engine speed, intake air pressure and temperature, and engine temperature) and calculated values for the engine control (duration of injection, timing of injection and ignition). 


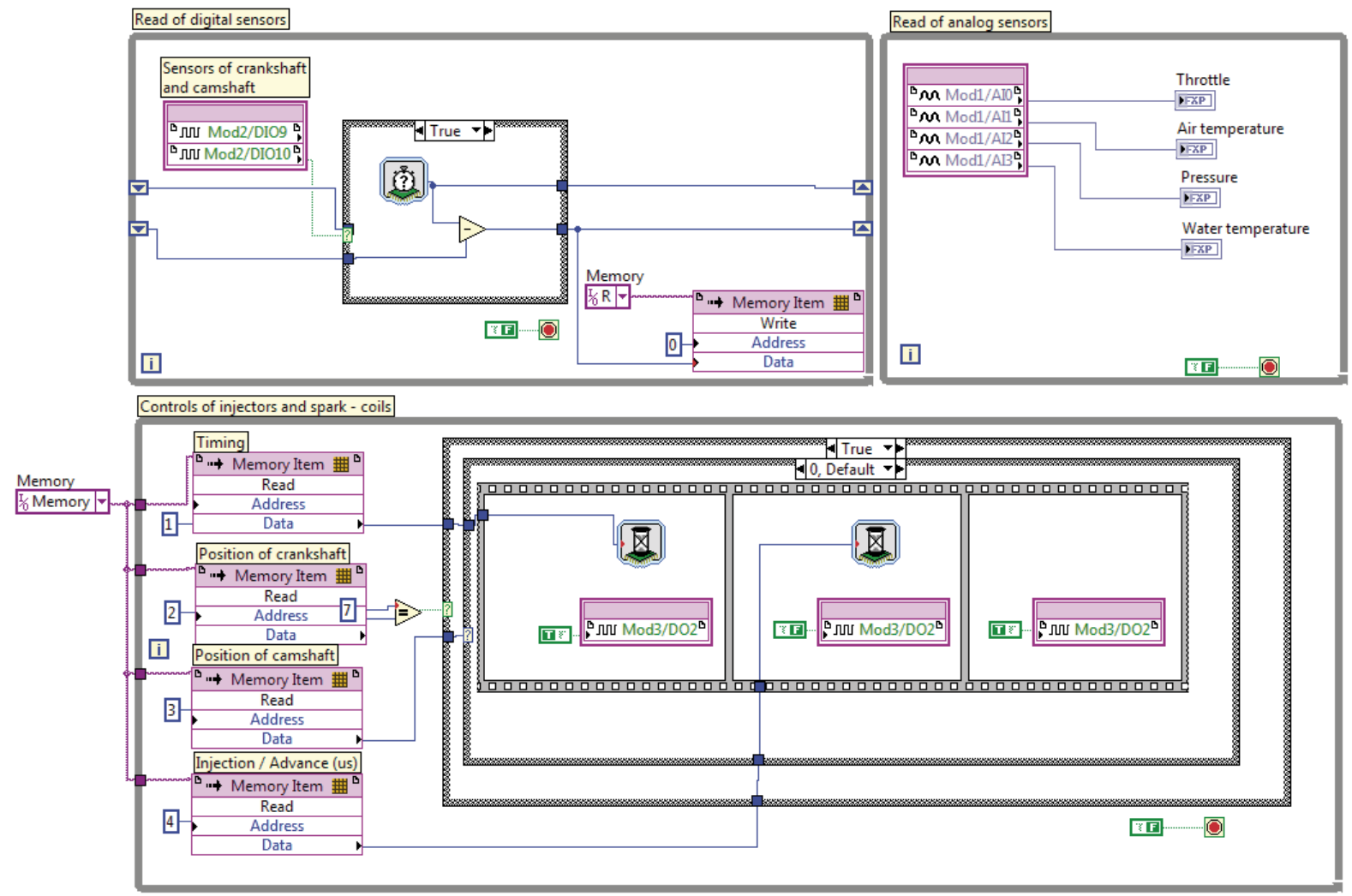

FIGURE 4: Block diagram of the FPGA program.

OBRÁZEK 4: Blokové schéma programu FPGA.

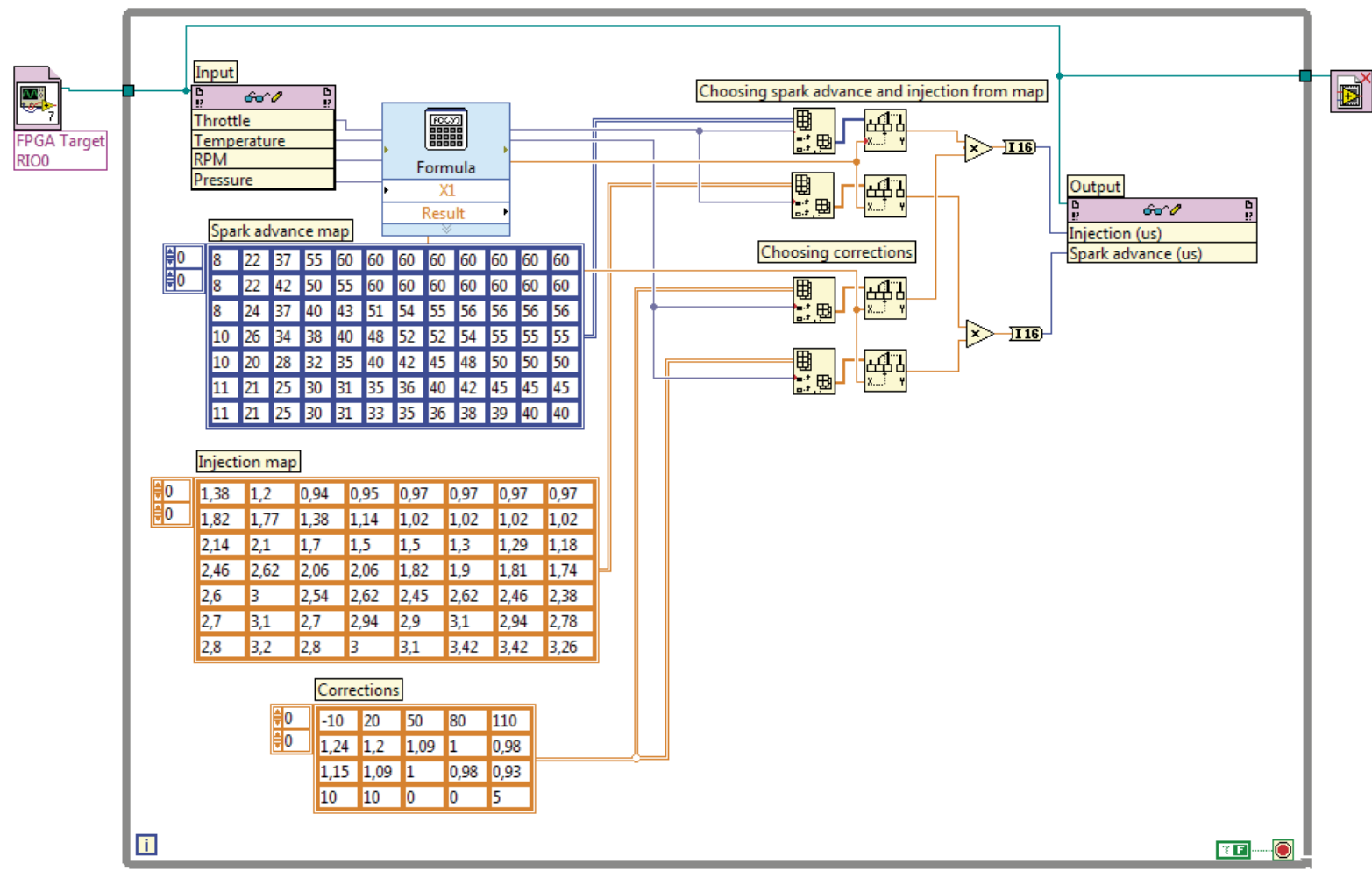

FIGURE 5: Simplified scheme of the controller block diagram.

OBRÁZEK 5: Zjednodušené schéma blokového diagramu kontroleru. 


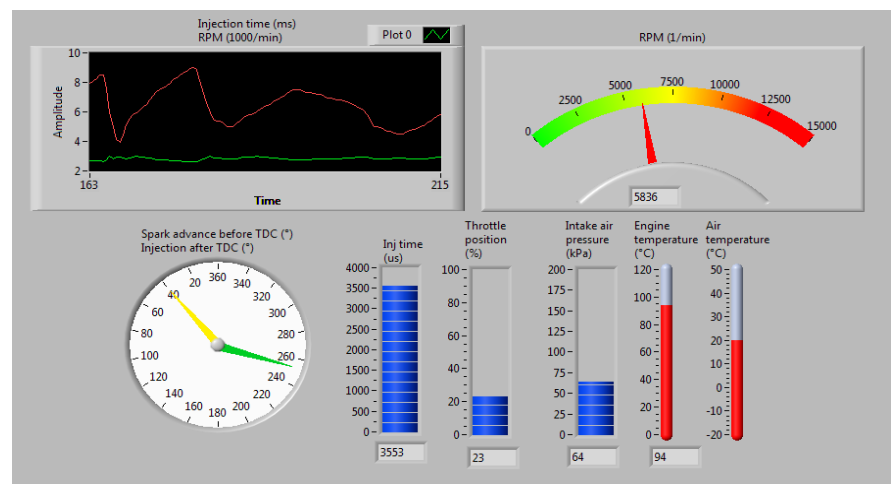

FIGURE 6: Front panel of the controller program [1].

OBRÁZEK 6: Informační panel programu pro kontroler [1].

\section{VERIFICATION OF THE CONTROL UNIT FUNCTIONS}

The YAMAHA YZF R6 engine was placed on the test stand during verification of the CompactRIO based ECU. The engine was managed by programmable ECU EFI EURO 4. The fuel maps and the spark advance map in the ECU EFI Euro 4 were set up on the basis of torque measurement on the engine test stand. The lambda sensor was used for optimizing of the A/F ratio for each cylinder separately during this measurement.

The test stand was equipped with toggle switches that enable selection of which ECU controls the engine. The engine can be fully controlled by the functional configuration of the ECU EFI EURO 4, or the ECU based on the CompactRIO can take over engine control. 8 switches are used -4 for injectors and 4 for ignition on the test stand for switching the ECUs, see Figure 1. Thus it is possible to control each cycle of each cylinder separately. Verification was done step by step, the engine was not loaded. Only one injector was driven at the beginning. When no difference in engine running was recognized, the control loop was applied for all injectors and the CompactRIO started to manage all the injectors.

The developed CompactRIO ECU handles control of the injectors very well, the unloaded engine was keep running at idle even at speeds around $10000 \mathrm{rpm}$. The engine also ran properly for an extended period without overheating of the transistors in the interface. No unusual phenomena in the software were identified during entire engine running. The values of injection duration, its timing and spark advance were checked on the front panel, see Figure 6, during the test. These values were the same as in the case where the engine was controlled by the EFI ECU. This affirms correct calculation of the controller program. Correct application of the ECU's data on the engine has not yet been tested. The correct injection and ignition timing will be checked in forthcoming studies. The control of ignition coils has been tested in the same way. However, the control of ignition is somewhat complex, because there are much higher demands on controlling of ignition energy and spark timing. Ignition energy and spark timing depend on switching on and off of the ignition coil. The main task is precise determination of switch-on time and dwell period for required engine speed. The engine has been running trouble free during testing at higher engine speed, but additional experimental work will be performed on setting up of the ignition control for low engine speed.

\section{CONCLUSION}

An engine control unit based on the NI CompactRIO was developed and tested on the running engine YAMAHA YZF R6. A suitable configuration of the NI CompactRIO has been designed consisting of the real-time controller, the analog input module for reading data from sensors, and the digital output module for engine control actuators (injectors, ignition coil).

The interface between the engine and the CompactRIO unit was built and successfully tested with the running engine. The power transistors need to be better cooled, or switching on by a steeper pulse has to be improved.

The test stand at the Josef Bozek Research Center of Engine and Automotive Engineering has been modified for engine management by two ECUs. Using switches, it is possible to select any combination of control of injectors and ignition coils for various of the engine's cylinders from the two different ECUs. The fuel injection system has been tested successfully and the tested engine has run at different engine speeds, although only without load. The CompactRIO is able to control engine ignition in general, but more work has to be done on setting up of the right switch-on time of the ignition coils.

\section{LIST OF ABBREVIATIONS \\ ECU engine control unit \\ TDC top dead center \\ TTL transistor - transistor logic \\ $\mathrm{NI} \quad$ National Instruments \\ FPGA field-programmable gate array \\ INJ injector \\ IC ignition coil \\ COP coil on plug \\ RS reset-set}

\section{REFERENCES}

[1] Strapko, M. (2011). Realizace ř́dicí jednotky spalovacího motoru s využitím platformy NI CompactRIO, ČVUT v Praze, Fakulta elektrotechnická, Bakalářská diplomová práce.

[2] Hruška, J. (2009). Návrh programu rídicí jednotky zážehového motoru YAMAHA R6. ČVUT v Praze, Fakulta strojní, Bakalářská práce BDP 2009-M23.

[3] http://www.sportrider.com

[4] http://www.ni.com/

[5] http://www.efitechnology.it

[6] http://www.etas.com/en/ 


\section{GUIDELINES FOR AUTHORS}

\section{A. LANGUAGE}

01) Language of paper - American English

02) Abstract, captions and keywords will be bilingual English and Czech, optionally English and Slovak. Authors from the Czech and Slovak Republic should prepare abstract, keywords and captions in English and native language. The abstract and captions for other authors will be translated by the publisher to Czech language.

\section{B. LENGTH}

Title should not exceed 10 words

Subtitle should not exceed 15 words

Abstract should not exceed 200 words

Paper without limit

\section{ORDER OF CONTENTS}

01) Title

02) Author(s) name: per author company/institute, address, and e-mail (on new line)

03) Abstract

04) Keywords

05) Body of the paper. The paper should be divided into logical numbered sections.

06) Preferred structure:

- Introduction: Background - Motivation - Goals

- Used methods

- Results

- Analysis of results and evaluation

- Conclusion: Result Utilization - Prospects

07) Acknowledgements

08) List of notations and abbreviations (in alphabetical order)

09) References

10) Appendices: Long derivation of equations, description and parameters of experimental equipment or methods, etc.

To facilitate the blind reviewing process, the authors are asked provide on a separate first page the items 1) and 2) and to start the main part of the article with 1) Title; and then 3) Abstract, and so on.

\section{GRAPHICAL ARRANGEMENT}

\section{Title: Times New Roman 17b, Bold}

Body of paper, abstract, equation numbering: Times New Roman $11 \mathrm{~b}$. Titles of sections Times New Roman 12b Bold. Symbols of physical quantities used in text: italic. SI units, wherever possible. Combined units should be written with dot (example: N.m, m.s. ${ }^{-2}, \ldots$ ).

Authors should avoid the usage of footnotes.

Captions: Times New Roman 10b, in bold - number and caption, normal - text of legend. See examples:

Figure 1: This is a figure.

Table 1: This is a table.

All illustrations should be numbered sequentially with arabic numbers. Equations: Times New Roman italic. Variable 12b, Index 7b, Small index 5b, Symbol 18b, Small symbol 12b. Mathematical operators and constants (Ex.: sin, e, $\pi, \ldots$ ) Times New Roman 12b normal.
All equations should be numbered sequentially with arabic numbers. List of notations either under every equation, or at the end of paper see paragraph $D$ (according to number and content of equations). Long derivation as appendix on the end of paper.

References: References referred in text in square brackets in format of text (Ex: [1])

Format of references, examples:

[1] Author A., Author B. and Author C. (2002). This is journal article, In: Journal for Interesting Papers, Vol. 10, No. 3, p. 130-145. ISSN

[2] Author A., Author B. and Author C. (eds.). Our Book on Car Technology, MIT Press, Massachusetts, 2002, p. 23-145. ISBN

[3] Author A., Author B. and Author C. (2002). My paper in a conference, In: Editor A., Editor B. and Editor C. (eds.) Proceedings Of Our Meeting in a Far Away Exotic Place, MIT Press, Massachusetts, p. 78-89. ISBN

\section{E. ILLUSTRATIONS}

The Journal is full-color.

The authors are responsible for delivering high-quality graphic material. In the case of illustrations sent via mail, the orientation of illustrations should be indicated, as well as their number in the article. The illustrations sent electronically, should be sent in the correct orientation and in a resolution at least $300 \mathrm{dpi}$, in common graphical formats.

\section{F. SUBMISSION OF MANUSCRIPTS}

Text should be in all cases prepared in electronical form. Paper can be sent via mail (the contents of mail should be illustrations and diskette $3,5^{\prime \prime}$ or CD with text), or via e-mail on the address mentioned below.

Text should be sent in format MS Word 2000 or older (format doc, or rtf). Do not merge illustrations in the text to avoid excessive file size All illustrations should be sent in separate files. No illustrations will be returned unless specifically requested.

Contact address for submission of paper:

ČVUT, FS, MECCA

Gabriela Achtenová

Technická 4, 16607 Praha 6, Czech Republic

Tel.: +4202243524 99, Fax: +420224352500

E-mail: gabriela.achtenova@fs.cvut.cz

\section{G. COPYRIGHT}

The papers submitted to journal MECCA have not been previously published or submitted elsewhere. The copyright of accepted papers becomes the property of Czech Technical University, and usage of any part of papers without permission of Czech Technical University will be not allowed. Authors who wish to reproduce already published illustrations should asked the permission by the copyright holder. Authors are asked to sign copyright agreement.

\section{H. PUBLICATION}

All articles will be blind reviewed. The first author, if no other contact person is marked, will be informed about the decision as soon as possible.

Authors will get 3 copies of the journal in which the article is published. 


\section{European Master's Degree in Automotive Engineering}

\section{Deadline for: - non EU students $1^{\text {st }}$ May 2012 \\ - EU students $30^{\text {th }}$ June 2012}

\section{Contact:}

\section{CTU in Prague}

Gabriela Achtenová

gabriela.achtenova@fs.cvut.cz Tel: +420 224352499

\section{ENSIETA}

\section{Yann Marco}

yann.marco@ensieta.fr

Tel: +33298348 844

\section{HAN}

Hans Vooren

h.vooren@han.nl

Tel: +31263658293

\section{Entrance level: Bachelor or equivalent}

\section{First year (2 semesters)}

taught in English by CTU in Prague - Czech republic

(intensive course of French language on Institut Francais de Prague included in the CTU Programme)

- engine, transmission, vehicle dynamics, CAD, vehicle design, structure and modelling,

- fluid dynamics,

- electronics in vehicle,

- manufacturing processes design, design of plastic tools and parts,

- communication and foreign language

- marketing, economy and company finance.

\section{$3^{\text {rd }}$ semester}

ENSIETA, Brest, France taught in French

\section{Common topics:}

Vehicle architecture, finite element method,

high technology materials,..

\section{2 specialisations:}

- Modelling structure analysis:

- explicit dynamics calculations.

- laws of behavior,...

- Vehicle design:

- road holding,

- brakes,

- exhaust system

- engines,

- human environment,...

\section{$4^{\text {th }}$ semester devoted to final thesis in an industrial or academic environment}

MASTER DEGREE IN AUTOMOTIVE ENGINEERING

Master diploma from 2 countries with respect to chosen specialisation in $3^{\text {rd }}$ semester

Next partner university for the $2^{\text {nd }}$ year:

* IFP, Paris, France offering 3 specializations taught in English and French.

For application form, detailed programme, studying conditions, tuition fees and all other informations, please see: 